УДК 930

DOI https://doi.org/10.31470/2518-7600-2021-11-91-112

\author{
RESIDENTIAL POINTS OF THE TERRITORY OF \\ «ZADNIPRSKY PLACES» OF HETMANATE
}

\title{
НАСЕЛЕНІ ПУНКТИ НА ТЕРИТОРІЇ «ЗАДНІПРСЬКИХ МІСЦЬ» ГЕТЬМАНЩИНИ
}

\section{НАСЕЛЕННЫЕ ПУНКТЫ НА ТЕРРИТОРИИ «ЗАДНИПРСКИХ МЕСТ» ГЕТЬМАНЩИНЫ}

Андрій Бутко,

аспірант кафедри історіі, археології, інформаційної та архівної справи

butandrej17@gmail.comhttps:// orcid: 0000-0002-8631-5112

Центральноукраӥнський національний Технічний університет, пр. Університетський,8,м. Kp Kropyvnytskyi, Ukraine, 25006 опивницький, Украӥна, 25006

\section{Andrii Butko,}

postgraduate at Department of History, Archeology, Information and Archives

affairsbutandrej17@gmail.comh ttps:// orcid: 0000-0002-86315112 Central Ukrainian National Technical University, 8, Prospekt Universytetsky,

\section{ABSTRACT}

This article is devoted to the problem of settlement of the "Dnieper places» of the Hetmanate and the emergence of settlements in this area, in the period from the beginning of the seventeenth - in the first half of the eighteenth centuries. The source base of the research is archival written and cartographic monuments. The research methodology is based on the principles of historicism, systematization, scientificity, verification, authorial objectivity, moderate narrative constructivism, as well as the use of general scientific (analysis, synthesis, generalization) and specialhistorical

(historical-genetic, historical-typological, 
historical-systemic) methods. The scientific novelty is that for the first time in the modern historiography of colonization of the Dnieper territories of the Hetmanate on the basis of little-studied and previously unknown archival documents and cartographic materials revealed the processes of origin, development, decline of settlements, clarified their number and status. In the course of colonization and economic development of the territory of the "Zadniprsky places» of the Hetmanate, several main periods can be distinguished. They are determined by changes in the number and status of settlements in this area during the seventeenth - first half of the eighteenth centuries.

In the 40's of the eighteenth century the least populated was the south of the "Zadniprsky places" of the Hetmanate, the north was somewhat more populated, but the central part of the territory was the most populated. In the second half of the 40's of the eighteenth century on the initiative of the hetman's administration, the colonization of the Zadneprovsky region intensified, which led to the formation of settlements, in particular, free villages.

In the early 50's of the eighteenth century there is a change in the status of "derevnya» to villages, and villages to towns, fortifications are laid, strengthened and expanded together with the surrounding village. The status of settlements was determined by the population, size, availability of administrative bodies, religious buildings and communities, economic orientation of the population.

Keywords: territory, colonization, Zadniprovsky places, Hetmanate, settlement, status.

Постановка проблеми. У ході колонізації та господарського освоєння Задніпровської території Гетьманщини можна виділити декілька періодів, які характеризуються зміною чисельності та статусу населених пунктів протягом XVII - першої половини XVIII століть. При цьому одні поселення виникали і розвивалися, доживаючи до сьогодення, а інші - занепадали та зникали. Тож існує необхідність наукового узагальнення даних писемних та 
картографічних джерел, історичних досліджень стосовно питання утворення населених пунктів на території «Задніпрських місць» Гетьманщини, часу їх заселення, статусу та чисельності. Власне статус населених пунктів обумовлювався кількома факторами: чисельністю населення, їх розмірами, наявністю адміністративних органів управління і релігійних споруд та общини, господарським спрямуванням занять населення.

Аналіз останніх досліджень і публікацій. Частково проблеми колонізації Задніпровських територій Гетьманщини торкався С. Шамрай ще у 1929 р. (Шамрай, 1929). Ним вперше опубліковано копію карти де Боскета, датовану 1763 роком, що супроводжувалася списком поселень без зазначення їх місця розташування. Він також наводить перелік поселень з більш пізніх прикордонних карт території краю 1755 р., але, як зазначає А. Пивовар, передача їх назв має досить сумнівний характер і в переважній більшості вони не можуть бути ідентифіковані з реально існуючими на той час поселеннями на території краю (Пивовар, 2003). Проблеми заселення Степової (Південної) України знайшли своє відображення в працях Н. Полонської-Василенко (Полонська-Василенко, 1960) та В. Пірка (Пірко, 2004). В них розглядаються питання стосовно процесів виникнення поселень на території південного Правобережжя Дніпра. Монографія А. Пивовара (Пивовар, 2003) - перша найбільш повна публікація документів XVII - першої половини XVIII ст. з описами «Задніпрських місць» Гетьманщини та населених пунктів, розміщених на цій території. Останнім часом з'явилося ряд статей, присвячених питанням урядової та народної колонізації, заселення та господарського освоєння території Задніпровських місць Гетьманщини (Січова, 2004; Шиян, 2012). На основі архівної джерельної бази в них дається загальна характеристика території Задніпровських місць Гетьманщини, розглядаються процеси, що сприяли появі поселень, а також характеризуються окремі з них. А втім, питання етапів виникнення та розвитку 
населених пунктів (поселень) на території «Задніпрських місць» Гетьманщини все ще залишається недостатньо дослідженим.

Мета статті. На основі писемних та картографічних джерел розкрити процеси заселення «Задніпрських місць» Гетьманщини та утворення на цій території населених пунктів у період з початку XVII - в першій половині XVIII століть.

Методологія дослідження. Окрім загальнонаукових методів в дослідженні використані й спеціально-історичні, а саме: хронологічний, історико-системний, історикогенетичний, історико-типологічний методи. Перший is зазначених методів дозволив розглядати формування поселень еволюційно, виділивши основні етапи заселення краю. Застосування історико-системного підходу сприяло формуванню цілісної картини впливу на колонізаційні процеси зовнішньо-політичного та військового факторів, а також дозволило визначити роль внутрішніх факторів реалізації політики уряду Гетьманщини стосовно Задніпровської території. Врешті історико-типологічний та історикогенетичний методи дозволили не лише виділити основні типи поселень на вказаній території, а й простежити зміну їх статусу, узгодити картографічні дані з описами території. Крім того, методологічно автори спиралися на працю В. М. Орлика, присвячену дослідженню волосько-молдавських поселень в Україні (Орлик, 1996). У цитованих джерелах 3 метою збереження автентичності тексту залишена орфографія оригіналів.

\section{Виклад основного матеріалу. Представлене} дослідження базується на використанні двох основних груп писемних документів: окремих документів, які містять інформацію про назви та статус населених пунктів на вказаній території та комплексні документи - описи території, переписи населених пунктів та населення в них, що здійснювалися 3 метою виявлення їх чисельності, місця розташування, права власності на них цивільних («посполитих»), службових 
(військових), духовних осіб, чисельності населення в них та їх соціального статусу.

Досліджувана нами територія вперше згадується в документах, що засвідчують земельну власність родини Волевачів, жителів м. Чигирин. Тестамент чигиринського козака Т. Ф. Волевача, датований 1601 р., містить згадки про поселення людей на правому березі р. Тясмин. Тихон Федорович лишив у спадок своїм синам Антону, Андрію та Івану пасіку на річці Чутка з дванадцятьма байраками, орним полем, сінокосами і хутором, а також хутір на річці Березівка (ЦДІАК України. Ф. 51. Оп. 3. Спр. 11437. Арк. 112-112 зв.). Іван Тихонович Волевач, знатний козак, по смерті батька і двох братів успадкував всю родинну нерухомість. У 1615 р. він купує ліс, що зветься Плоский, який розташований на витоках p. Цибульник. У купчій зазначається, що при лісі ще $\epsilon$ дванадцять байраків з малими байраками, звірине поле і хуторище із сінокосом, степом і поселенням людей (ЦДІАК України. Ф. 51. Оп. 3. Спр. 11437. Арк. 109). У 1648 р., перебуваючи на посаді обозного Війська Запорозького, Іван Волевач додає до своїх володінь пасіку, яка простяглася до p. Інгулець. На Інгульці теж була гребля i хуторище 3 поселенням людей, сінокосами, полем, рибними і звіриними ловами (ЦДІАК України. Ф. 51. Оп. 3. Спр. 11437. Арк. 193196; ІР НБУВ, Ф. ІІ. Д. 1965. Арк. 941-945).

Таким чином, зародження хуторського способу ведення господарства за р. Тясмин розпочалося на початку XVII ст. й залишалося основним до середини XVIII ст. Поступово до середини XVII ст. кількість хуторів за Тясмином збільшилась, але була незначною. В основному це були хуторські господарства заможної полкової та сотенної старшини Чигиринського полку. Точними даними тогочасної їх кількості ми не володіємо за браком історичних джерел.

Історичні дані про стан розвитку колонізаційних процесів протягом $50-80 \mathrm{x}$ pp. XVII ст. на просторі за р. Тясмин та p. Вись від р. Дніпро до р. Синюха, а також військово-політичні 
відносини між Гетьманщиною та сусідніми державами не дають підстав стверджувати про існування на зазначеній території сталих поселень будь-якого статусу. Можливі активні військові дії, незахищеність території військовою силою Гетьманщини від нападів ворога та постійна загроза розрухи, спалення житлових і господарських споруд, а також можливість потрапити в турецько-татарський полон унеможливлювала ведення та стабільний розвиток хутірського господарства.

За умовами «Трактату про Вічний мир» територія на південь від Тясмина мала перебувати у складі Московського царства, а містечка вздовж Правобережжя Дніпра по русло p. Тясмин планувалося звільнити від населення та в подальшому залишати незаселеними, що обумовлювалося їх прикордонним положенням. Ймовірно, саме кінцем XVII ст. можна датувати перші заселення поселенців в Криловській слободі та деякі поселення на Правобережжі Тясмину. Їх населення було прийшлим з однойменних населених пунктів (сіл) вздовж Лівобережжя Тясмину - Калантаїв, Андрусівка. Одночасно засновується і заселяється ряд хуторів. Але в цілому територія залишалася все ще малозаселеною. Наявні документи дають досить обмежені та неповні відомості про «задніпрські поселення» Миргородського полку, які були заселені до 1710 р., зокрема донесення капітана Абакумова 1746 р. в Комісію економії описаних маєтностей: «сотни Власовской село Табурище поселение имеет до шведской баталии, деревня Конотоп поселение имеет до шведской баталии; сотни Кременчуцкой село Круков поселение имеет до шведской баталии, деревня Свинярня поселение имеет перед шведскою баталиею» (ЦДІАК України. Ф. 1632. Оп. 1. Спр. 181. Арк. 62-62 зв.).

За умовами Прутського миру між Московським царством і Османською імперією, протягом 1711-1712 рр. відбувалося примусове відселення українського населення 3 території Правобережжя Дніпра разом з відходом козацьких полків та російської армії на Лівобережжя Дніпра - зокрема, до 
Миргородського полку Гетьманщини. За підтримки Порти, польська шляхта почала захоплювати землі за Тясмином, де створює поселення та заселяє їх протягом 2-3-го десятиліття XVIII ст.

У цей період на задніпровській території Правобережжя Тясмину мешканці придніпровських сотень Миргородського полку Гетьманщини вели свої промисли. Значна частина населення була вихідцями з колишнього Чигиринського полку, що перейшли на помешкання в Малоросійські полки в 17111712 pp. За ведення промислів польська адміністрація примушувала платити грошовий збір.

В 1732 р. відповідно до скарги гетьмана Д. Апостола та генеральної старшини до російського уряду про захоплення i освоєння цієї території поляками, не зважаючи на протест 3 боку польської шляхти Речі Посполитої, територія була повернута в підпорядкування Гетьманщини під протекторатом Російської імперії. Вперше був здійснений опис прикордонних 3 Польщею територій та реєстр на них поселень (ЦДІАК України. Ф. 51. Оп. 3. Спр. 11437. Арк. 193-196; ІР НБУВ. Ф. II, Д. 1965. Арк. 941-945). Описи включають три види поселень - «старинные», «новопоселенные» і «поселенные вновь». До «старинных» належали поселення, залюднені українцями, а згодом захоплені польською шляхтою. До таких поселень віднесені села Табурище, Кам'янка, «деревни» Золотарівка, Обломіївка, Конотоп, Свинарня, Білецьківка, Пацьківка, Круків, що знаходилися вздовж узбережжя Дніпра до гирла р. Тясмин. В описі зазначено, що ці населені пункти здавна були заселені козаками і посполитими, але поляк Казимир Чайковський насильно захопив їх і привів у польське підданство. До «старинных», ймовірно, можна віднести зазначене в описі без уточнення часу заснування, але відомого з інших давніших джерел, с. Войтове на р. Тясмин. Далі, на р. Ірклій розміщувалась, очевидно, старопоселена «деревня» Нестерівка. До населених пунктів вздовж берега Тясмина, що існували раніше, але занепали і обезлюднили та «вновь от 
поляков поселенных», віднесені слобода Криловська, «деревня» Воропцівка, с. Андрусівка. До «новопоселенных» поляками поселень, відносилась слобода Походіївка вище гирла р. Тясмин, слобідка Колонтаївська, розміщена далі на березі цієї ж річки. Під Чорним лісом розмістилося «новопоселенное от поляков» село Цибулеве, нижче, поблизу р. Інгулець, під лісом Чутою - хутір Тонконогий. Ряд «новопоселенных» населених пунктів у період польської колонізаційної діяльності були заселені вздовж р. Цибульник: «деревні» Ковалівка, Биківка, Глинська, хутори Григорія Ревенка, Юська Головача, хутір Федорки. При гирлі р. Цибульник розміщувався «старопоселенный» хутір Скубіївка.

Опис території «Задніпровських місць» дав можливість визначити масштаби колонізаційної політики польської влади. 324 (25. - Авт.) населених пунктів, зазначених в описі, 11 (12. - Авт.) були заселені до приходу поляків. У період відсутності в регіоні російсько-українських військ з 1711 р. по 1732 р. поляки відновили тут 3 спустошені населені пункти і заселили 10 нових (Січова, 2004: 39-40). Заселили новозасновані поселення українці, вихідці 3 території «Малой Росии» та меншою мірою - вихідці «з Польської области». Захоплені поляками старозасновані поселення розміщувалися, переважно, вздовж узбережжя р. Дніпро, новопоселені - вглиб території, по річках Інгулець та Цибульник. Відповідно поселення, які були заново відбудовані, знаходилися вздовж узбережжя р. Тясмин. Всі населені пункти, які згідно з описом знаходилися в межах Російської імперії, були відібрані від поляків i перейшли в підпорядкування сотників Придніпровських сотень Гетьманщини. Новостворені поляками поселення, з 1732 р. перейшли у підпорядкування представника Миргородської полкової канцелярії, який перебував у Криловській слободі та виконував обов'язки сотника. Південніше володінь Придніпровських сотень Миргородського полку розміщувались угіддя Придніпровських 
сотень Полтавського полку. Але значних населених пунктів там ще не було, окрім, ймовірно, невеликої кількості хуторів, що на той час ще не були внесені в описи та реєстри.

Підписання Белградської мирної угоди 1739 р. передбачало визначення російсько-турецького кордону. Останнє обумовило проведення чергового розмежування та опису кордону з Польщею в 1740 р., оскільки польська шляхта, скориставшись послабленням колонізаційних процесів на території «Задніпрських місць» Гетьманщини протягом 2-3-го десятиліть XVIII ст., освоювала та заселяла територію під своїм контролем (Караката, 1967: 38-40; Шамрай, 1929: 212-213). Після російсько-турецької війни 1735-1739 рр., територія остаточно закріплюється за Російською імперією.

3 початку 40-х pp. XVIII ст. генеральна старшина Гетьманщини та полкова старшина Миргородського й Полтавського полків за схваленням російського імперського уряду на «відібраній» у поляків задніпровській території посилюють та поширюють політику колонізації від Дніпра і Тясмина в напрямку до річок Синюхи і Бугу. Відновлюються та заселяються старі поселення. Протягом 1740-1742 pp. відбувалося досить інтенсивне заселення краю. Виникають і заселяються нові поселення, особливо в більш західних районах, що до 1739 p. не контролювалися i були малообжитими та незаселеними.

В описах «Задніпрських місць» 1745 р., представлених в Сенат при рапорті підполковника Данила де Боскета від 9 січня 1752 р., маємо відомості про задніпровські поселення: «малоросийских Миргороцкого и Полтавского полков от «1740» по «1745» год по старинным крепостям и по давним заимам в тех Заднепрских местах вновь поселения имеется» (РГАДА. Ф. 248. ОП. 39. Д. 2667. Арк. 83-83 зв.). Відомість №3 містить дані про число задніпровських поселень Придніпровських сотень Полтавського полку, а відомісті № 47 - про число «задніпрських» поселень Придніпровських сотень та Криловської сотні Миргородського полку. За цими 
даними в сотні Криловській містечок - 1, сіл - 8, деревень - 5, хуторів - 15. Перерерахунок чисельності поселень, що його здійснив автор, дає дещо інші числові показники: містечок -2, сіл -7 , слобід - 2, деревень -5 , хуторів - 16 (з них один відноситься до Власівської сотні). Містечко Цибулеве в описі зараховане як село, а слободи не зазначені. За описом в сотні Власівській: сіл - 1, «деревень» - 6, хуторів - 30, а в перерахунку: сіл -1 , «деревень» -6 , хуторів - 29 (один 3 хуторів знаходиться на території Криловської сотні). За описом в сотні Кременчуцькій: село - 1, «деревня» - 1, хуторів 3 греблями та без гребель - 38. В перерахунку отримуємо: хуторів 37, але якщо рахувати жилий двір хорунжого Миргородського полку Максима Леонтієва як хутірське поселення, тоді кількість хуторів у підсумку збігається 3 кількістю, зазначених в описі. В сотні Потоцькій: село - 1 , хуторів козачих - 34, посполитих -5.

У складі Миргородського полку на тій стороні Дніпра, за даними опису, розміщуються: Петрів Острів, при Березняк буйраці: хутір - 1, городок Архангельске, а в ближніх байраках річок Синюхи, Торговиці та Висі: хуторів - 3. Всього в Миргородському полку вищезазначених сотень: городків - 1 , «местечок» - 1, сіл - 11, «деревень»-13, хуторів - 129, тоді як в перерахунку маємо: хуторів 126, сіл 11, «деревень» 12, слобід 2, містечок 3. Разом, 154 населені пункти на 1745 р.

В сотні Келебердянській: село - 1, «деревень» - 6, хуторів - 8. В сотні Переволочанській: слобід - 1, «деревень» - 3, хуторів - 1. В сотні Орлянській: «деревня» - 1, хутір - 1. Всього в Полтавському полку вищезазначених сотень: слобід - 1, село - 1, «деревень» - 10, хуторів - 10 (РГАДА. Ф. 248. ОП. 39. Д. 2667. Арк. 86-107).

В кінці описів маємо запис: «всего Миргороцкого и Полтавского полков в Заднепрских местах от «740» по «745» год поселения имеется: городов два, сел тринатцать, деревень дватцать три, хуторов сто тритцать деветь» (РГАДА. Ф. 248. ОП. 39. Д. 2667. Арк. 107). За цими даними в підсумку маємо 
177 населених пунктів на 1745 р., але в перерахунку виходить менша кількість: хуторів 136, сіл 12, деревень 22, слобід 3 , містечок 2, городок 1. Разом, 176 населених пунктів.

Вищенаведені дані вимагають певних уточнень, а саме: до складу Криловської сотні записані деякі поселення, що згодом увійшли до складу Цибулівської сотні; віддалені західні поселення на річках Вись та Синюха не були включені до складу Криловської сотні, а пізніше ввійшли до складу Архангелогородської сотні; в підсумковому записі до описів городок Архангельський та містечко Крилов, записані як «города», слобода Мишуриноріжска Переволочанської сотні записана як село.

За результатами дослідження та описом території Задніпровських місць 1745 р. була складена карта, виконана де Боскетом у тому ж році. На ній були позначені майже всі новозасновані чи поновлені після російсько-турецької війни 1735 - 1739 рр. поселення. Карта супроводжувалася описом місця розташування переважно найбільших поселень (Отдел Рукописей Библиотеки Академии Наук России. Д. 545; Інститут Картографії НБУВ. Дд. 43528, 43530). Нижче наведемо орієнтовні місця розташування поселень 3 опису карти «Задніпрських місць» Данила де Боскета 1745 р.: в долині p. Тясмин (від впадіння в р. Дніпро до м. Старий Чигирин) містечко Крилов; в долині р. Цибульник (від впадіння в p. Дніпро до витоків від лісу Чута); на правому березі р. Дніпро (вниз від р. Цибульник до устя р. Омельник); в долині p. Омельник Келебердянський; на правому березі р. Дніпро між річками Омельниками Келебердянським і Переволочанським; в долині р. Омельник Переволочанський; у верхів'ях р. Малий Інгулець (від устя річок Жовтої та Зеленої до витоків за Чорним лісом); річка Кам'янка (зліва), у вершині річки - кордон Миргородського та Полтавського полків; при безіменній балці (Мала Кам'янка); при усті балки зліва; у верхів'ях Кам'янки зліва; між устям Кам'янки та Березовки; праворуч від устя Березівки (Малої); вище - друга р. Березівка, при ній хутори; 
навпроти устя Березівки на Інгульці; на безіменній річці (Березівка Велика) - хутори, вздовж безіменної річки (Макариха) - хутори; вище, до безіменної річки (Говнянка) хутори; від річки Говнянки до річки Чорноліски (праворуч, в Чорному лісі) - хутори; проти устя Чорноліски - містечко Цибулів; в лівобережному басейні р. Вись (від р. Синюха до верхів'їв вздовж російсько-польського кордону); в лівобережному басейні Синюхи (від р. Вись до р. Чорний Ташлик); річка Торговиця, ліворуч від устя - фортеця Архангельська (Пивовар, 2003: 188-189).

Отже, на середину 40-х рр. XVIII ст. зазначена територія залишалася все ще малозаселеною, якщо враховувати ії площу та розміри природних угідь. Так, в Полтавському полку зафіксована лише одна слобода. Ймовірно, що для прискорення інтенсивності заселення краю, урядова старшина Гетьманщини поширює слобідський тип поселення на Задніпровській території, а полкова та сотенна старшина впроваджують їх на місцях. Це дало позитивну динаміку в процесі заселення краю та зростання чисельності населення, а також кількості населених пунктів.

На початок 50-х pp. XVIII ст. маємо документально підтверджені дані про населені пункти на території «Задніпрських місць», із зазначенням їх назви та приналежності власникам. Це, зокрема, опис «задніпрських» поселень Миргородського полку квітня 1752 р. (ЦДІАК України. Ф. 51. Оп. 3. Спр. 11144. Арк. 32-38), який включає інформацію про населені пункти Криловської, Цибулевської Архангелогородської, Власівської, Кременчуцької, Потоцької сотень.

Опис «задніпрських» поселеннь Миргородського полку, який було зроблено для графа О. Розумовського в листопаді 1752 р., включає такий перелік населених пунктів: хуторів 167, сіл 10, «деревень» і слобід 25, містечок 5. Разом 207 населених пунктів на 1752 р. (ЦДІАК України. Ф. 51. Оп. 3. Спр. 11144. Арк. 53-54). Водночас опис задніпровських поселень 
Полтавського полку 1752 р. містить відомості про поселення Келебердянської та Переволочанської сотень (IP НБУВ. Ф. II. Спр. 63. Д. 59330. Арк. 61-78; Д. 59307-59308).

Дещо інша ситуація вимальовується під час аналізу карти «задніпрських» володінь Келебердянської і Переволочанської сотень Полтавського полку 1752 р. На ній позначено більше поселень, порівняно з вищезгаданим описом (ЦДІАК України. Ф. 51. Оп. 3. Спр. 11437. Арк. 1). Карта представляє собою умовне зображення території межиріччя Дніпра та Інгульця, 3 нанесеними долинами річок та балок, вздовж яких умовними знаками відображено розташування населених пунктів 3 підписами їх назв. При цьому на ній відображено значно більше населених пунктів, ніж наведено в описі «задніпрських» поселень Полтавського полку 1752 р. В підсумку на карті позначено 45 населених пунктів та 1 фортецю. Водночас на карті не позначені окремі хутори, відомі за описом, як от значкового товариша Хоми Лиха, козака переволочанського Семена Петрова, вдови Явдохи Стрельнички, військового товариша Степана Рудя. Карту в березні 1752 р. було надіслано разом 3 матеріалами опису «задніпрських» володінь Келебердянської і Переволочанської сотень в Полтавську полкову канцелярію за підписом сотників полкового полтавського Г. Штепи та келебердянського М. Козельського. Виявлені розбіжності в чисельності позначених на карті населених пунктів та даними опису обумовлені більш точним iï складанням. Останнє могло бути спричинене передачею задніпровської території козацьких сотень під поселення сербів та пов'язаним з цим можливим отриманням компенсації виселенцям - власникам дворів, хуторів та інших поселень.

Опис задніпровських поселень Полтавського полку 1752 р. включав поселення Орлянської сотні (ІР НБУВ. Ф. II. Спр. 63. Д. 59321. Арк. 41-42 зв.; Д. 59335). У підсумку вимальовується така картина чисельності населених пунктів на задніпровській території сотень Полтавського полку: хуторів 32+4+13; сіл - 4+1; «деревень» - 4; слобід - 5; фортеця - 1 .

Разом - 64 населених пункти на 1752 p. 
Таблиия 1

Кількість населених пунктів «Задніпрських місць» на 1745, 1752 pp.

\begin{tabular}{|c|c|c|c|c|c|c|c|c|}
\hline \multirow[t]{2}{*}{ Полк } & \multirow{2}{*}{$\begin{array}{l}\text { роки наявних } \\
\text { відомостей }\end{array}$} & \multicolumn{6}{|c|}{ чисельність населених пунктів, їх статус } & \multirow[t]{2}{*}{ разом } \\
\hline & & $\begin{array}{l}\text { кількість } \\
\text { городків }\end{array}$ & $\begin{array}{l}\text { кількість } \\
\text { містечок }\end{array}$ & $\begin{array}{c}\text { кількість } \\
\text { сіл }\end{array}$ & $\begin{array}{c}\text { кількість } \\
\text { слобід }\end{array}$ & $\begin{array}{c}\text { кількість } \\
\text { «деревен } \\
\text { ь» }\end{array}$ & $\begin{array}{c}\text { кількість } \\
\text { хуторів }\end{array}$ & \\
\hline $\begin{array}{c}\text { Мирг. } \\
\text { п. }\end{array}$ & 1745 & 1 & 2 & 11 & 2 & 12 & 126 & 154 \\
\hline $\begin{array}{c}\text { Полт. } \\
\text { п. }\end{array}$ & 1745 & - & - & 1 & 1 & 10 & 10 & 22 \\
\hline Разом & & 1 & 2 & 12 & 3 & 22 & 136 & 176 \\
\hline $\begin{array}{c}\text { Мирг. } \\
\text { п. }\end{array}$ & 1752 & - & 5 & 10 & 12 & 13 & 167 & 207 \\
\hline $\begin{array}{c}\text { Полт. } \\
\text { п. }\end{array}$ & 1752 & 1 & & 5 & 5 & 4 & 49 & 64 \\
\hline Разом & & 1 & 5 & 15 & 17 & 17 & 216 & 271 \\
\hline
\end{tabular}

Висновки. Наведені вище матеріали свідчать, що 3 початку і до середини 40-х pp. XVIII ст. найменш заселеним був південь «Задніпрських місць» Гетьманщини, тоді як на півночі їх кількість дещо зростала, а найбільш заселеною виявилася центральна частина території. Ймовірно, така ситуація була обумовлена кількома факторами: географічним (природніми умовами території - більш рівнинним рельєфом, наявністю більшої кількості річок та джерел та криниць питної води та ін.); демографічною ситуацією (північна частина території була заселена раніше інших, тому для заселення залишалися центральні та південні райони); фактором військової загрози (перспективною видавалась центральна рівновіддалена від кордонів Туреччини й Речі Посполитої, а відтак, більш безпечної для поселенців-колонізаторів). Найбільша кількість поселень розміщувалась у Кременчуцькій і Потоцькій сотнях Миргородського полку, найменша - у Криловській та Орлянській. Найпоширенішим видом поселень був хутір, що було спричинено бажанням поселенців до ведення звичного власного хутірського господарства. Це підтверджує факт розвитку початкової «народної» колонізації території. Поширеними були не притаманні для 
центральноукраїнських земель «деревни» - так в тогочасному російському статистичному діловодстві записувалися населені пункти без церкви. Сіл нараховувалось у два рази менше, ніж «деревень». Церков і священників у міських і сільських поселеннях було, ймовірно, мало й вони не могли задовольнити достатньою мірою релігійні потреби населення. Особливо це стосувалося малозаселеної задніпровської території Полтавського полку, де зовсім не було поселень міського типу, нараховувалось одне село i одна слобода. Поселень слобідського типу на задніпровської території Миргородського полку було всього два, що говорить про незначний тогочасний рівень розвитку урядових колонізаційних процесів на Задніпровській території Гетьманщини. Та все ж початок урядової колонізації території відбувався з Придніпровської території Миргородського полку і далі на захід, що виявлялося у відновленні, утворенні та заселенні населених пунктів, зокрема стратегічних містечок Крилов, Цибулеве, Архангелогородка.

Вже у другій половині 40-х рр. XVIII ст. генеральна та полкові адміністрації за підтримки російського уряду активізують колонізацію Задніпровського краю, результатом чого стало зростання інтенсивності заселення краю та утворення населених пунктів. Набуває значно ширшого розповсюдження такий тип поселень, як слобода, 3 привабливими умовами для поселенців. Майже на порядок збільшується кількість хуторів.

На початок 50-х рр. XVIII ст. кількість сіл збільшується на 3 одиниці за рахунок «деревень», в яких будуються церкви та зростає кількість населення. Два села набувають статусу містечка, а також закладається, укріплюється і розростається один ретраншемент $з$ поселенням - селом. Крім того, деяка частина поселенців проживала в окремих господарських дворах, на пасіках, при млинах.

Тож на 1745 рік нараховувалося 176 старих новозаселених та нових населених пунктів, а на 1752 рік їх 
кількість збільшується майже на 100 одиниць, до 271 (таблицяя 1). Це вказує на поновлення та подальший інтенсивний розвиток колонізаційних процесів на задніпровській території Миргородського і Полтавського полків Гетьманщини з початку 40-х pp. XVIII ст., на їх значне зростання в другій половині 40-х рр. - на початку 50-х рр. XVIII ст.

Назви переважної більшості хуторів, «деревень», слобод, сіл були похідними від імені або прізвища (прізвиська) першопоселенця, засновника або власника, в деяких випадках - від назви населеного пункту, звідки переселились колонізатори. В багатьох випадках назви поселенням надавалися за географічним фактором, від місця розташування на місцевості (похідні назви від назв річок, рельєфу, гірських порід, грунтів, наявності поблизу лісових масивів та деяких інших). Назви містечок, городків, в основному, визначалися географією місця розташування, походили від населеного пункту, звідки відбулося переселення, від імені святих у православ ї.

Містечка й городки, як правило, були укріпленими, а також мали фортецю 3 військовою, переважно, козацькою залогою, на випадок збройного захисту жителів під час військових дій, загроза якої була постійною на прикордонній території Задніпровського краю. Крім того, вони були опорними пунктами Гетьманщини під час колонізації території за Дніпром, виконували роль збірних пунктів для новоприбулих поселенців, що бажали тут оселитися. 3 початку 40-х рр. XVIII ст. і на початок 50-х pp. XVIII ст. на території «Задніпрських місць» існували укріплення-фортеці в Табурищі, Крукові, Крилові, Цибулеві, Архангелогороді, Петроострові, Новому Миргороді, які входили до складу Миргородського полку, а в Мішуриному Розі - до Полтавського полку (Чорний, 2016: 263). Містечка Крилів, Цибулів, Архангелогород були також адміністративними центрами однойменних сотень. 


\section{ДЖЕРЕЛА ТА ЛІТЕРАТУРА}

1. Інститут Картографії Національної бібліотеки України ім. В. Вернадського. Дд. 43528, 43530.

2. Інститут рукописів Національної бібліотеки України ім. В. Вернадського. Ф. ІІ. Д. 1965. Арк. 941-945; Спр. 63. Д. 59330, Д. 59307-59308, Д. 59321, Д. 59335.

3. Российский Государственный Архив Древних Актов. Ф. 248. Оп. 39. Д. 2667.

4. Центральний державний історичний архів України, м. Київ. Ф. 51. Оп. 3. Спр. 11144, Спр. 11437; Ф. 1632. Оп. 1. Спр. 181.

5. Отдел Рукописей Библиотеки Академии Наук России. Д. 545.

6. Караката М. М. Давнє минуле Андрусівки (Історія села). 50-річчю Радянської влади присвячується. Київ, 1967. 112 с.

7. Орлик В.М. До питання волосько-молдавських поселень на Україні. Київ: КДЛУ, 1996. 31 с

8. Пірко В.О. Заселення і господарське освоєння Степової України в XVI-XVIII ст. Український культурологічний центр. Донецьк: Східний видавничий дім, 2004. 224 с.

9. Пивовар А.В. Поселення Задніпрських місць до утворення Нової Сербії в документах середини XVIII століття. Київ: Академперіодика, 2003. 336 с.

10. Полонська-Василенко Н.Д. Заселення Південної України в половині XVIII століття (1734-1775). Ч. 1. Заселення Нової Сербії та Слов'яносербії. Мюнхен: Український вільний університет, 1960. 222 с.

11. Січова О. В. Витоки і початковий етап колонізації південних земель Правобережжя i приєднання їх до Гетьманщини (перша третина XVIII століття). Вісник Київського національного університету імені Тараса Шевченка, Історія, 2004. 74-76. С. 37-40.

12. Січова О. В. 3 історії колонізації південних земель Правобережжя i приєднання їх до Гетьманщини (перша третина XVIII століття). Рукописна та книжкова спадщина 
України. Київ: Нац. б-ка України ім. В.І. Вернадського, 2004. Вип. 9. С. 112-120.

13. Шамрай С. До історії залюднення Степової України в XVIII столітті (Крилівщина і Лизаветщина). Записки історикофілологічного відділу ВУАН, 1929. Кн. XXIV. С. 207-302.

14. Шиян Р. «Фронтир зовнішній» і «фронтир внутрішній»: концепція південноукраїнського прикордоння між 1680-ми1750-ми роками. Наукові праці історичного факультету Запорізького національного університету. Запоріжжя: ЗНУ, 2012. Вип. XXXII. С. 96-105.

15. Чорний О. Система земляних укріплень в Задніпрських місцях Миргородського полку до утворення Нової Сербії. «Археологія \& Фортифікація України». Збірник матеріалів VI Міжнародної науково-практичної конференції. Відп. ред.О. О. Заремба. Кам'янець-Подільський: ПП Буйницький O.A., 2016. C. 263.

\section{REFERENCES}

1. Karakata, M. M. (1967). Davnye mynule Andrusivky (Istoriya sela) [The ancient past of Andrusivka (History of the village)]. Kyiv, 112 [in Ukrainian]

2. Orlyk, V.M. Do pytannya volos'ko-moldavs'kykh poselen' na Ukrayini. [On the issue of Wallachian-Moldavian settlements in Ukraine], Kyiv: KDLU, 31 [in Ukrainian].

3. Pirko, V.O. (2004). Zaselennia i hospodars'ke osvoiennia Stepovoi Ukrainy v VI-XVIII st. [Settlement and economic development of Steppe Ukraine in the XVI-XVIII centuries]. Ukrayins'kyy kul'turolohichnyy tsentr. Donets'k: Skhidnyy vydavnychyy dim [in Ukrainian].

4. Pyvovar, A. V. (2003). Poselennja Zadniprs'kih misc' do utvorennja Novoi Serbii v dokumentah seredyny XVIII stolittja [Settelment of Zadniprs'kykh places before foundation of Nova Serbia in the documents of XVIII century]. Kyiv: Akademperiodyka [in Ukrainian]. 
5. Polons'ka-Vasilenko, N.D. (1960). Zaselennja Pivdennoi Ukrainy v polovyni XVIII stolittja (1734-1775) (Vol. 1) [The Settlement of the Southern Ukraine in the middle of the XVIII century]. Mjunhen: Ukrains'kyj vil'nyj universytet [in Ukrainian].

6. Sichova, O. V. (2004). Z istorii kolonizatsii pivdennykh zemel' Pravoberezhzhia i pryiednannia ikh do Het'manschyny (persha tretyna XVIII stolittia). [From the history of the colonization of the southern lands of the Right Bank and their accession to the Hetmanate (the first third of the XVIII century)]. Rukopysna ta knyzhkova spadschyna Ukrainy. (9), 112-120 [in Ukrainian].

7. Sichova, O. V. (2004). Vytoky i pochatkovyi etap kolonizatsii pivdennykh zemel' Pravoberezhzhia i pryiednannia ikh do Het'manschyny (persha tretyna XVIII stolittia). [Origins and initial stage of colonization of the southern lands of the Right Bank and their accession to the Hetmanate (the first third of the XVIII century)]. Visnyk Kyivs'koho natsional'noho universytetu imeni Tarasa Shevchenka, Istoriia, (74-76), 37-40 [in Ukrainian].

8. Shamray, S. (1929). Do istorii zaliudnennia Stepovoi Ukrainy v XVIII stolitti (Krylivschyna i Lyzavetschyna). [To the history of settelments of Steppe Ukraine in the XVIII cen. (Krylivshchyna i Lyzavetchyna)]. Zapysy istorychno-filolohichnoho viddilu VUAN. XXIV, 207-302 [in Ukrainian].

9. Shyian, R. (2012). «Frontyr zovnishnij» i «frontyr vnutrishnij»: kontseptsiia pivdennoukrains'koho prykordonnia mizh 1680-my-1750-my rokamy. [«Frontier external» and «frontier internal»: the concept of the southern Ukrainian borderline between 1680 and 1750]. Naukovi pratsi istorychnoho fakul'tetu Zaporiz'koho natsional'noho universytetu, XXXII, 96-105 [in Ukrainian].

10. Chornyy, O. (2016) Systema zemlyanykh ukriplen v Zadniprskykh mistsyakh Myrhorodskoho polku do utvorennya Novoyi Serbiyi. [The system of earth fortifications in the Dnieper areas of the Myrhorod Regiment before the formation of New Serbia] «Arkheolohiya \& Fortyfikatsiya Ukrayiny». Zbirnyk materialiv VI Mizhnarodnoyi naukovo-praktychnoyi konferentsiyi. 
Vidp. red.O. O. Zaremba. Kamyanets-Podilskyy: PP Buynytskyy O.A, 263 [in Ukrainian].

\section{АНОТАЦІЯ}

Ця стаття присвячена проблемі заселення «Задніпрських місиьь» Гетьманщини та виникненню на иій території населених пунктів у період з початку XVII - в першій половині XVIII століть. Джерельною базою дослідження виступають архівні писемні та картографічні пам'ятки. Методологія дослідження базується на принципах історизму, системності, науковості, верифікації, авторської об'єктивності, а також на використанні загальнонаукових (аналіз, синтез, узагальнення) та спеціально-історичних (історикогенетичний, історико-типологічний, історико-системний) методів. Науковою новизною є те, щуо вперше в сучасній історіографії колонізації Задніпровських територій Гетьманщини на основі малодосліджених та невідомих раніме архівних документів, картографічних матеріалів розкрито процеси виникнення, розвитку, занепаду населених пунктів краю, з 'ясовано їх чисельність та статус.

Хід колонізації та господарського освоєння території «Задніпрських місиь» Гетьманщини можна поділити на кілька основних періодів, які характеризуються змінами чисельності та статусу населених пунктів на зазначеній території протягом XVII - першої половини XVIII століть.

У 40-х рр. XVIII cm. найменш заселеним був південь «Задніпрських місиь» Гетьманщини, дещо більше заселеною була північ, а найбільш заселеною виявилася центральна частина зазначеної території. У другій половині 40-х рр. XVIII cm. $з$ ініціативи гетьманської адміністрації колонізація Задніпровського краю активізується, щзо призвело до утворення населених пунктів, зокрема слобід. На початку 50-х рр. XVIII cm. спостерігається зміна статусу «деревень» на села, а сіл-на містечка, закладаються, укріплюються $i$ розростаються фортифікаиійні споруди разом із прилеглим 
селом. Статус населених пунктів визначався чисельністю населення, розмірами, наявністю адміністративних органів управління, релігійних споруд та общини, господарським спрямуванням населення.

Ключові слова: територія, колонізація, Задніпровські місия, Гетьманщуина, поселення, статус.

\section{АННОТАЦИЯ}

Данная статья посвящена проблеме заселения «Заднепрских мест» Гетманщинны и возникновению на этой территории населенных пунктов, в период с начала XVII - в первой половине XVIII столетия. Материальной базой исследования выступают архивные письменные $и$ картографические источники. Методология исследования базируется на принципах историзма, системности, научности, верификации, авторской объективности, конструктивизма, а также на использование общуенаучных (анализ, синтез, обобщуение) и специиально-исторических (историко-генетический, историко-типологический, историко-системныци) методов. Научной новизной является то, что впервые в современной историографии колонизачии Заднепровских территорий Гетманщины на основе малоисследованных и неизвестных ранее архивных документе, картографических материалов раскрыто прочессы возникновения, развития, упадка населенных пунктов края, установлено их численность и статус.

Ход колонизации и хозяйственного освоения территории «Заднепрских мест» Гетманшины можно поделить на несколько основных периодов, характеризуюшихся изменениями численности и статуса населенных пунктов на указанной территории в течение XVII- первой половины XVIII веков. В 40-х г2. XVIII в. наименее заселенным был юг «Заднепрских мест» Гетманщины, несколько больше заселенным был север, а наиболее заселенной оказалась центральная часть указанной территории. Во второй 
половине 40-х г2. XVIII в. по инициативе гетманской администрации колонизация Заднепровского края активизируется, что привело к образованию населенных пунктов, в частности, слобод. К началу 50-х г2. XVIII в. наблюдается изменение статуса «деревень» на села, а сел на города, закладываются, укрепляются и разрастаются фортификационные сооружения вместе с прилегающим селом. Статус населенных пунктов определялся численностью населения, размерами, наличием административных органов управления, религиозных сооружений и общины, хозяйственным направлением населения.

Ключевые слова: территория, колонизация, Заднепровские места, Гетманшина, поселения, статус. 